\title{
Development and validation of a data logger for thermal characterization in laying hen facilities
}

\author{
Letícia C. da S. R. Freitas ${ }^{1}$, Ilda de F. F. Tinôco으, Richard S. Gates ${ }^{2}$, Matteo Barbari², \\ Márcia G. L. Cândido ${ }^{1} \&$ João V. Toledo ${ }^{4}$
}

\begin{abstract}
${ }^{1}$ Universidade Federal de Viçosa/Departamento de Engenharia Agrícola. Viçosa, MG, Brasil. E-mail: leticiacibele@yahoo.com.br (Corresponding author) - ORCID 0000-0002-9607-4092; iftinoco@hotmail.com - ORCID: 0000-0002-8152-0301; marciagl.candido@gmail.com - ORCID: 0000-0001-9100-4397

${ }^{2}$ University of Illinois at Urbana-Champaign/Department of Agricultural and Biological Engineering. Urbana, IL, EUA. E-mail: rsgates@illinois.edu - ORCID: 0000-0003-2812-1739

${ }^{3}$ Università degli Studi di Firenze/Department of Agricultural and Forest Engineering. Firenze, Itália. E-mail: matteo.barbari.unifi.it - ORCID: 0000-0002-0760-8604

${ }^{4}$ Universidade Federal do Espírito Santo/Departamento de Ciências Florestais e da Madeira. Jerônimo Monteiro, ES, Brasil. E-mail: jvitor_agr@yahoo.com.br ORCID: 0000-0002-9712-4776
\end{abstract}

\begin{abstract}
The environmental monitoring in animal facilities that includes collected data storage in a robust, practical and feasible way is a constant challenge. The aim of this study was to develop a reliable data logger for monitoring the air temperature and air relative humidity of aviaries and to assess the adequacy of the design using commercially available reference standard instruments. The experimental data logger was installed together with a commercial data logger, a mercury thermometer and a calibrated Vaisala HMP110 air relative humidity probe in a meteorological shelter. Linear regression analysis was performed with the collected air temperature and air relative humidity to develop calibration equations. The Nash-Sutcliffe Index and the relative error were calculated to validate the experimental data logger. The air temperature and the air relative humidity calibration equations presented Nash-Sutcliffe of 0.993 and -0.281 for the commercial data logger, and 0.913 and 0.932 for the experimental data. The mean relative error of the air temperature readings was 3 and $1 \%$ and for air relative humidity 5 and $20 \%$, for the experimental and commercial logger, respectively. The experimental data logger reliably stored all collected data without error to the micro-SD card. The experimental data logger can be considered low-cost and sufficiently accurate for monitoring air temperature and air relative humidity in aviaries, presenting field performance very close to the commercial data logger for air temperature measurement, and better performance than the commercial data logger for the measurement of air relative humidity.
\end{abstract}

Key words: electronic device, environmental monitoring, poultry facilities

\section{Desenvolvimento e validação de um data logger para caracterização térmica em instalações de poedeiras}

RESUMO: O monitoramento ambiental em instalações animais, que inclui o armazenamento de dados coletados de forma robusta, prática e viável, é um desafio constante. O objetivo deste estudo foi desenvolver um data logger confiável para monitorar a temperatura e umidade relativa do ar dos aviários e avaliar a adequação do projeto usando instrumentos padrão de referência comercialmente disponíveis. O data logger experimental foi instalado junto com um data logger comercial, um termômetro de mercúrio e uma sonda de umidade relativa do ar calibrada Vaisala HMP110 em um abrigo meteorológico. A análise de regressão linear foi realizada com a temperatura e a umidade relativa do ar coletadas, para desenvolver equações de calibração. O índice Nash-Sutcliffe e o erro relativo foram calculados para validar o data logger experimental. As equações de calibração de temperatura do ar e de umidade relativa do ar apresentaram Nash-Sutcliffe de 0,993 e - 0,281 para o data logger comercial e, 0,913 e 0,932 para o data logger experimental. O erro relativo médio das leituras de temperatura do ar foi de 3 e $1 \%$ e da umidade relativa do ar 5 e 20\%, para o data logger experimental e comercial, respectivamente. $\mathrm{O}$ data logger experimental armazenou de forma confiável todos os dados coletados, sem erro, no cartão micro-SD. O data logger experimental pode ser considerado de baixo custo e suficientemente preciso para monitoramento da temperatura do ar e da umidade relativa do ar em aviários, apresentando desempenho de campo muito próximo ao data logger comercial para medição da temperatura do ar e melhor desempenho que o data logger comercial para medição da umidade relativa do ar.

Palavras-chave: dispositivo eletrônico, monitoramento ambiental, instalações avícolas

Ref. 207723 - Received 12 Jul, 2018 • Accepted 23 Aug, 2019 • Published 28 Aug, 2019 


\section{INTRODUCTION}

The continuous monitoring of the thermal environment throughout the production cycle is necessary to provide ideal environmental conditions for animals in real time while balancing other inputs such as energy and feed. Unfortunately, few specialized companies provide the implementation of these safe, affordable and reliable environmental monitoring systems, which makes this practice relatively onerous (Djajadi \& Wijanarko, 2016) and thus, unlikely to be deployed.

Husain et al. (2016) and Ünsal et al. (2016) developed a low-cost, portable and easily manageable device to monitor air quality in urban settings. In agriculture and animal production, Roldán et al. (2015) developed a device for environmental control in greenhouses, Chao et al. (2000) and Gates et al. (2001) developed alternatives to conventional staged ventilation control in animal production, and Li et al. (2015) developed a henhouse online monitoring system based on wireless sensor network. Torres et al. (2015) set up a low-cost meteorological station and verified a good correlation between the measured data and the recorded data from a conventional automatic weather station.

In the international poultry industry, studies related to the automation of the real-time environmental monitoring of the facilities are being carried out with the aim of optimizing environmental control (Li et al., 2015; Hongqian et al., 2016; Ji et al., 2016). However, for the Brazilian poultry industry, automated environmental monitoring in a practical and operable way is still a challenge to be overcome.
The aim of this study was to develop a reliable data logger from easily-obtained and available electronic components for monitoring the air temperature and air relative humidity of aviaries, and to assess the adequacy of the design using commercially available reference standard instruments.

\section{Material ANd Methods}

The experimental device consisted of electronic components connected to the Arduino Mega 2560 board, as depicted in Figure 1.

The technical characteristics of the components included the following:

- Arduino Mega 2560 - Board based on the ATmega2560 microcontroller, with 54 digital input/output channels, 16 analog input channels, four UARTs (serial hardware ports), a $16 \mathrm{MHz}$ crystal oscillator, a USB connection, a power outlet, an ICSP header, and a reset button. The operating voltage is five volts.

- RTC module DS 1302 - Module controlled by the DS1302 chip type RTC (Real Time Clock), with functions of date, time and calendar. The RTC provides information for hours, minutes, seconds, day of week, date, month, and year, and automatically adjusts for months less than 31 days and leap years. In addition to its electronic components, it has a backup battery (CR2032) to keep the power to the chip in case of power failure or disconnect.

- Liquid Crystal Display - A HD44780 controller with 16 columns and two rows, and utilizing an I2C interface which

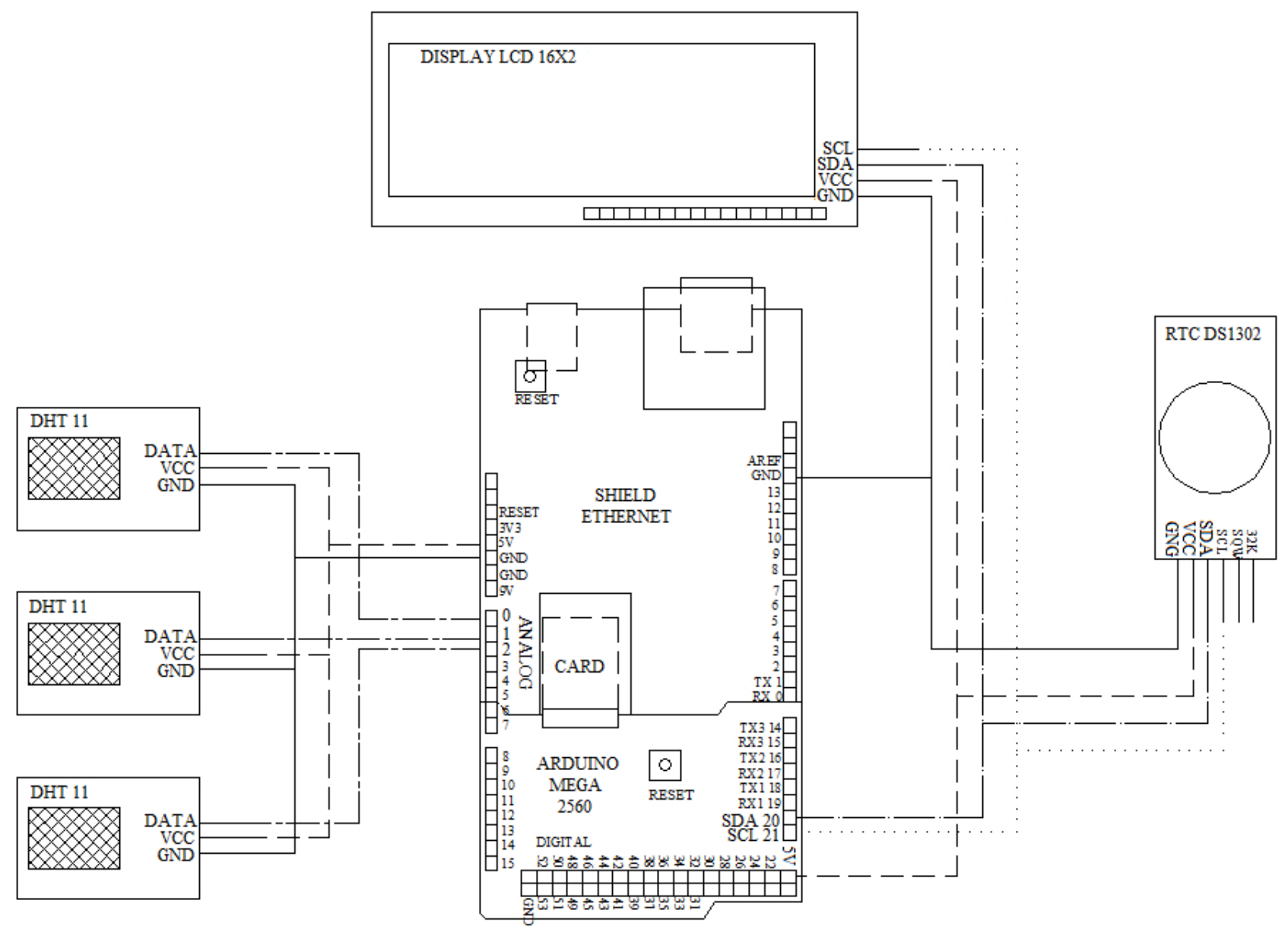

Figure 1. Schematic of the connections between sensors, electronic components and Arduino board 
allows control with only two pins. The display is used to present the measurements, as well as the date and time provided by the RTC.

- Ethernet shield - a secondary prototype board (“Shield”) with a Wiznet W5100 ethernet chip, capable of connecting the Arduino board to the internet. It also has micro-SD card slot for storing data files.

- DHT11 - Air temperature and air relative humidity sensor containing a calibrated digital output signal (D-Robotics, 2018). Utilizing digital technology ensures measurement reliability, excellent long-term signal stability, and is widely used in applications for environmental monitoring, because of its small size, low power dissipation and strong signal interference rejection. The DHT11 includes a resistive element for the measurement of air relative humidity and an NTC thermistor element for air temperature measurement (Ma et al., 2014; D-Robotics, 2018). The manufacturer's specifications are: air temperature from 0 to $50{ }^{\circ} \mathrm{C}$, accuracy of $\pm 2{ }^{\circ} \mathrm{C}$; and air relative humidity from 20 to $95 \%$, accuracy of $\pm 5 \%$. Signal lengths of up to $20 \mathrm{~m}$ using $\mathrm{I} 2 \mathrm{C}$ communications are possible (D-Robotics, 2018).

- IDE - Integrated Development Environment (IDE) is the Arduino open-source software development platform, available free of charge via the internet.

The DHT11 sensors, a commercial data logger (HOBO U14-001, Onset Computer Corp., Bourne MA, USA), a mercury thermometer and a calibrated air relative humidity sensor (HMP110, Vaisala, Helsinki, Finland) were installed in the weather station of an educational institution located in the municipality of Viçosa, MG, Brazil, geographic coordinates $20^{\circ}$ $46^{\prime} 18^{\prime \prime} \mathrm{S}$ and $42^{\circ} 52^{\prime} 21^{\prime \prime} \mathrm{W}$ and altitude of $688 \mathrm{~m}$.

The mercury thermometer and the Vaisala HMP 110 probe were considered reference standard instruments for air temperature and air relative humidity, respectively. The Vaisala HMP110 probe has excellent stability and accuracy of $\pm 1.5 \%$ (0 to $90 \% \mathrm{RH}$ ) and $\pm 2.5 \%$ (90 to $100 \% \mathrm{RH}$ ), besides being easily calibrated with saline solutions (Vaisala, 2018).

To relate air temperature and air relative humidity measured by the reference standard devices (independent variables) with the air temperature and air relative humidity measured by the experimental and commercial data logger (dependent variables), regression analyses were performed in Sigma Plot. The regression model was linear as shown in Eq. 1:

$$
\mathrm{Y}_{\mathrm{i}}=\beta_{0}+\beta_{1} \mathrm{X}_{\mathrm{i}}+\mathrm{e}_{\mathrm{i}}
$$

where:

$Y_{i} \quad$ - i-th observation of the dependent variable, measured air temperature or air relative humidity;

$X_{i}$ - i-th observation of the independent variable, reference air temperature or air relative humidity;

$\beta_{0}$ - intercept, linear coefficient;

$\beta_{1}$ - slope, angular coefficient; and,

$e_{i} \quad$ - random error associated with the pair, $X_{i}, Y_{i}$.

Intercepts and slopes were tested for zero and unity, respectively, (hypothesis test $\mathrm{H}_{0}: \beta_{0}=0$ or $\beta_{1}=0$ and $\mathrm{H}_{1}: \beta_{0}$ $\neq 1$ or $\beta_{1} \neq 0$ ) using the Student " $\mathrm{t}$ " test at $\mathrm{p} \leq 0.05$. The air temperature and air relative humidity data of the devices were collected at one-hour intervals for $24 \mathrm{~h}$.

The calibration equation for the experimental and commercial data loggers was determined by inverting Eq. 2 and computing estimated values of $\mathrm{X}_{\mathrm{i}}\left(\mathrm{X}_{\mathrm{i}}{ }^{\prime}\right)$ from measured values, $\mathrm{Y}_{\mathrm{i}}$ :

$$
\mathrm{X}_{\mathrm{i}}^{\prime}=\frac{\left(\beta_{0}-\mathrm{Y}_{\mathrm{i}}\right)}{\beta_{1}}
$$

where:

$\mathrm{X}_{\mathrm{i}}^{\prime}$ - estimated values of air temperature or air relative humidity.

Twenty-five experimental dataloggers were fabricated and used with a total of seventy-five DHT11 sensors in a larger study of the thermal environment of laying hen aviaries. In this study, are reported only the efforts taken to first verify the performance of the calibration equations and further validate the experimental data logger design. The three experimental data loggers and two commercial data loggers were installed in the corridors between cages at the center of one commercial aviary (Figure 2), located in the southern region of the state of Minas Gerais, Brazil, geographic coordinates $22^{\circ} 19^{\prime} 53^{\prime \prime} \mathrm{S}$ and $44^{\circ} 55^{\prime} 14^{\prime \prime} \mathrm{W}$ and altitude of $892 \mathrm{~m}$.

The high-hen density aviary is a galvanized steel structure with uninsulated steel roof panels, and has dimensions of $134 \times 12.5 \mathrm{~m}$ (length $\mathrm{x}$ width), with a $5 \mathrm{~m}$ ridge height and $1.2 \mathrm{~m}$ wide covered open ridge. Inside the facilities there were four batteries of vertical cages, each with six tiers. Each cage has dimensions of $0.6 \times 0.5 \times 0.4 \mathrm{~m}$ (width $\mathrm{x}$ depth $\mathrm{x}$ height), housing with eight to ten birds per cage, with density

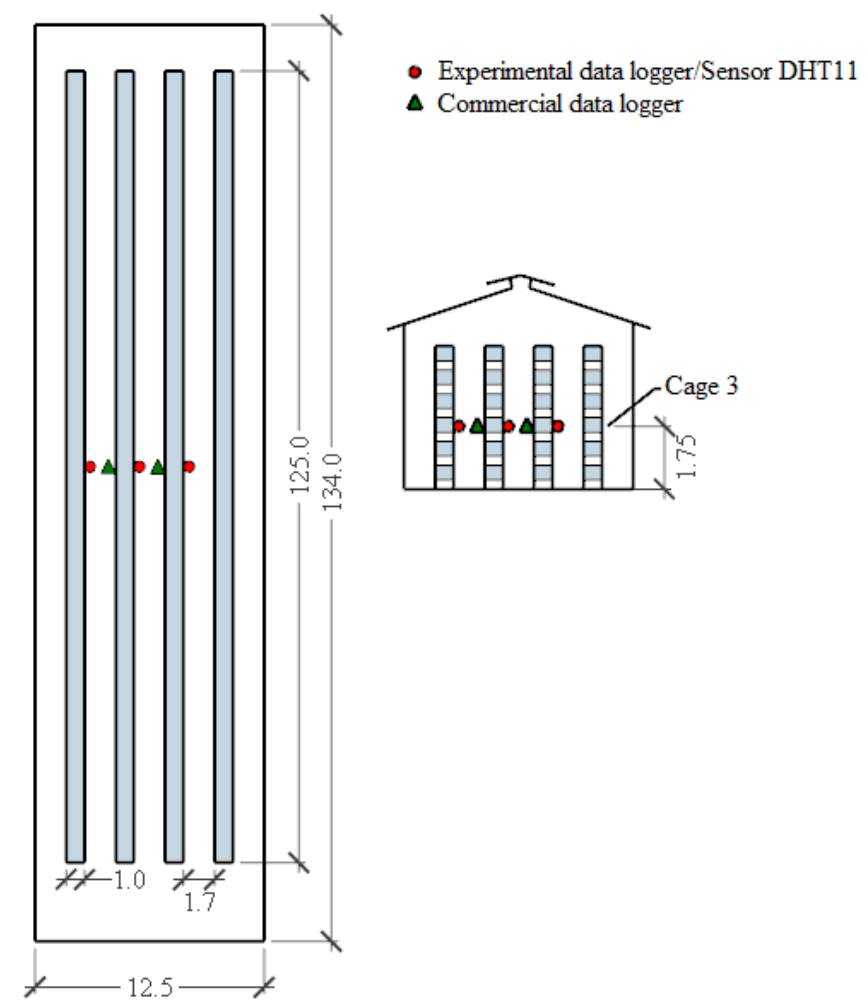

Dimensions in meters

Figure 2. Layout of the data loggers in the laying hens' facilitie 
between 300 to $375 \mathrm{~cm}^{2}$ bird ${ }^{-1}$. Each aviary on the farm can accommodate up to 100,000 laying hens of the Hy-Line W-36 lineage.

Data were collected during six consecutive days and the hourly values of air temperature and air relative humidity, for each experimental and commercial data logger were corrected using Eq. 2.

To evaluate the performance of the calibration equations, the Nash-Sutcliffe efficiency (NSE) index (Nash \& Sutcliffe, 1970) was used. This index is a normalized statistic that determines the relative importance of the residual variance in comparison with the variance of the measured data (Gupta et al., 1999). The index was calculated by Eq. 3:

$$
\mathrm{NSE}=1-\left[\frac{\sum_{\mathrm{i}-1}^{\mathrm{n}}\left(\mathrm{Y}_{\mathrm{i}}^{\text {measured }}-\mathrm{Y}_{\mathrm{i}}^{\text {calibrated }}\right)^{2}}{\sum_{\mathrm{i}-1}^{\mathrm{n}}\left(\mathrm{Y}_{\mathrm{i}}^{\text {measured }}-\mathrm{Y}_{\mathrm{i}}^{\text {mean }}\right)^{2}}\right]
$$

where:

$$
\begin{aligned}
& \text { NSE - Nash-Sutcliffe efficiency index; } \\
& Y_{i}^{\text {measured }} \text { - } i \text {-th measured value; } \\
& Y_{i}^{\text {calibrated }} \text { - calibrated value; } \\
& Y_{i}^{\text {mean }} \text { - mean of the measured value; and, } \\
& n \quad \text { - total number of observations. }
\end{aligned}
$$

In addition to the NSE index, validation of the experimental data logger was also tested from the relative error between the average values obtained by the experimental and commercial data loggers.

For the calculation of the NSE and relative error, the hourly mean values of the three experimental data loggers and the two commercial data loggers were used during the six days of data collection.

\section{Results AND Discussion}

Table 1 presents the equations coefficients of the line, standard errors (SE) and coefficients of determination $\left(\mathrm{R}^{2}\right)$ obtained by the regression analysis for air temperature and air relative humidity measured by experimental data logger and commercial data logger HOBO U14-001. The air temperature and air relative humidity measured used in the regression analysis ranged from 9.25 to $26.00{ }^{\circ} \mathrm{C}$ and 37 to $73 \%$, respectively.

The intercept and slope coefficients of the commercial data logger air temperature regression were not significant ( $p>0.05)$, which indicates that the data of the air temperature values measured by the commercial data logger are statistically the same as those measured by the mercury thermometer under consideration as a reference standard.

The regression slope represents the instrument's static sensitivity and the standard error of the slope quantifies the uncertainty in this estimate. A perfect instrument would have a slope of unity and zero standard error. The calibration equations obtained by inversion of the regression equations are given in Table 2 .

The standard error for the calibration equations for the experimental data logger $\left( \pm 0.485^{\circ} \mathrm{C}\right.$ and $\left.\pm 2.257 \%\right)$ were lower than the errors reported by the manufacturer of the DHT11 sensor which is $\pm 2{ }^{\circ} \mathrm{C}$ and $5 \%$ (D-Robotics, 2018). For the commercial data logger equation, the standard error of the estimate of air temperature was found to be greater $\left( \pm 0.436{ }^{\circ} \mathrm{C}\right)$ than that indicated by the manufacturer, $\pm 0.21^{\circ} \mathrm{C}$ and for air relative humidity smaller $( \pm 1.882 \%)$ than the one indicated by the manufacturer, $\pm 2.5 \%$ (Onset Computer Corporation, 2018).

The coefficients of determination $\left(\mathrm{R}^{2}\right)$ of the equations exceeded 0.950 indicating that more than $95 \%$ of the variation of the air temperature and relative humidity of the air measured by the experimental data logger is explained by the air temperature and air relative humidity variation measured by the mercury thermometer and Vaisala probe HMP110. This value is above that considered acceptable by Santhi et al. (2001), Liew et al. (2003) and Moriasi et al. (2007), which is 0.50.

The air temperature and air relative humidity results collected in the center of the commercial aviary for the experimental and commercial data loggers installed in the center in the laying hens' aviary, corrected by calibration equations are presented in Figure 3.

The experimental data logger underestimated the values measured mainly for low air temperatures and air relative humidities (Figures 3A and $\mathrm{C}$ ). The air temperature values calculated by the commercial data logger calibration equation have a nearly perfect relationship with the observed values (Figure 3B). However, the values of air relative humidity are underestimated (Figure 3D).

Table 2. Calibration equations of air temperature and air relative humidity measured by experimental and commercial data loggers

\begin{tabular}{lccc}
\hline & \multicolumn{1}{c}{ Equation } & SE & $\mathbf{R}^{2}$ \\
Air temperature & & & \\
Experimental data logger & $\mathbf{X}^{\prime}=-2.631+1.076^{\star} \mathrm{Y}$ & 0.485 & 0.992 \\
Commercial data logger & $\mathrm{X}^{\prime}=-0.413+1.007^{\mathrm{n}} \mathrm{Y}$ & 0.436 & 0.993 \\
\hline Air relative humidity & & & \\
Experimental data logger & $\mathrm{X}^{\prime}=-12.414+1.193^{*} \mathrm{Y}$ & 2.257 & 0.977 \\
Commercial data logger & $\mathrm{X}^{\prime}=-17.853+1.120^{\star} \mathrm{Y}$ & 1.882 & 0.984 \\
\hline
\end{tabular}

\begin{tabular}{|c|c|c|c|c|c|c|}
\hline & $\beta_{0}$ & $\beta_{1}$ & SE & $\mathrm{SE}_{\beta 0}$ & $\mathrm{SE}_{\beta 1}$ & $\mathrm{R}^{2}$ \\
\hline \multicolumn{7}{|l|}{ Air temperature } \\
\hline Experimental data logger & $2.445^{\star}$ & $0.929 *$ & 0.451 & 0.313 & 0.0175 & 0.992 \\
\hline Commercial data logger & $0.410^{\text {ns }}$ & $0.993^{\text {ns }}$ & 0.433 & 0.301 & 0.0168 & 0.993 \\
\hline \multicolumn{7}{|l|}{ Air relative humidity } \\
\hline Experimental data logger & $10.403^{*}$ & $0.838^{*}$ & 1.891 & 1.609 & 0.0270 & 0.977 \\
\hline Commercial data logger & $15.943^{*}$ & $0.893^{*}$ & 1.681 & 1.431 & 0.0240 & 0.984 \\
\hline
\end{tabular}

$\mathrm{X}^{\prime}$ - Value corrected $\left({ }^{\circ} \mathrm{C}\right.$ and \%); Y - Value measured $\left({ }^{\circ} \mathrm{C}\right.$ and \%); SE - Standard errors $\left({ }^{\circ} \mathrm{C}\right.$ and \%); ${ }^{*}$ - Statistically significant at $\mathrm{p} \leq 0.05$ by $\mathrm{t}$ test; $\mathrm{ns}$ - Not significant; $\mathrm{R}^{2}$ - coefficient of determination

Table 1. Equation coefficients of the line, standard errors (SE) and coefficients of determination $\left(\mathrm{R}^{2}\right)$ obtained by the regression analysis

$\beta_{0}$ - Intercept, linear coefficient $\left({ }^{\circ} \mathrm{C}\right.$ and $\left.\%\right) ; \beta_{1}$ - Slope, angular coefficient $\left({ }^{\circ} \mathrm{C}\right.$ and $\left.\%\right)$; SE - Standard errors $\left({ }^{\circ} \mathrm{C}\right.$ and $\left.\%\right) ;{ }^{*}$ - Statistically significant at $\mathrm{p} \leq 0.05$ by t test; ns - Not significant 
A.

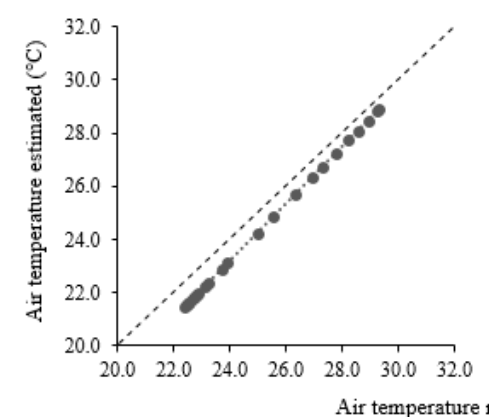

C.

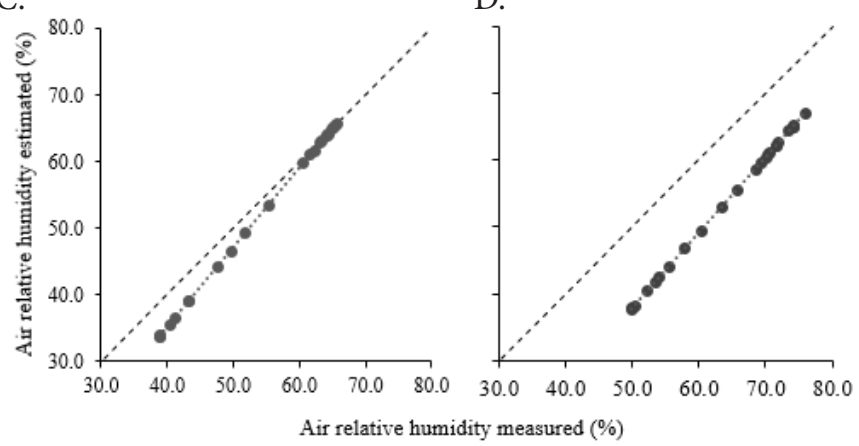

Figure 3. Air temperature and relative humidity of the air measured and estimated according to the calibration equation obtained for: A and C - experimental data logger; B and D commercial data logger

The performance of the experimental and commercial data loggers calibration equations was evaluated by the NSE. For air temperature, the NSE was 0.993 for the commercial data logger and 0.913 for the experimental data logger. For air relative humidity, the NSE indices were -0.281 and 0.932 for commercial and experimental data loggers, respectively. The Nash-Sutcliffe index (NSE) of one unity indicates perfect correspondence between the values predicted by the calibration equation and the measured values. A NSE index of zero suggests that the prediction is as accurate as the average of the measured data and, below 0 , the equation is considered worse than the simple mean of the measurement (Ahmad et al., 2010). For Miranda et al. (2014), the NSE represents the distance relationship between the corrected data and the observed average data behavior.

The Nash-Sutcliffe index has been applied effectively in the evaluation of the performance of hydrological models (Miranda et al., 2014; Pereira et al., 2016), Global radiation models (Deo et al., 2016), and models of dry matter accumulation and rice yield (Ribas et al., 2016).

Average hourly values of air temperature and relative humidity of the air as measured, adjusted by calibration, and the relative error between them, for the experimental and commercial data loggers, are displayed graphically in Figure 4.

For the air temperature, the experimental data logger showed an average relative error of $3 \%$. For air temperatures between 20 and $25^{\circ} \mathrm{C}$ the relative error was around $4 \%$ and at air temperatures above $25^{\circ} \mathrm{C}$ it reduced to around $2 \%$ (Figure $4 \mathrm{~A})$. For air relative humidity, the experimental data logger presented an average relative error of 5\%. For air relative humidity in the range from 60 to $70 \%$, the relative error was close to zero and for the air relative humidity from 30 to $40 \%$,
A.

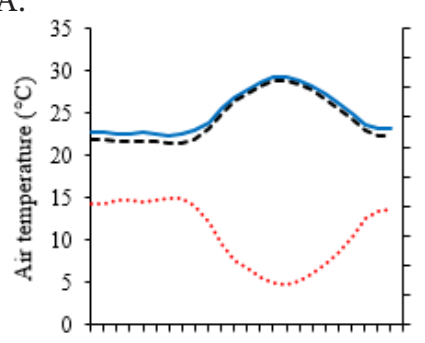

B.

$$
\text { C. }
$$

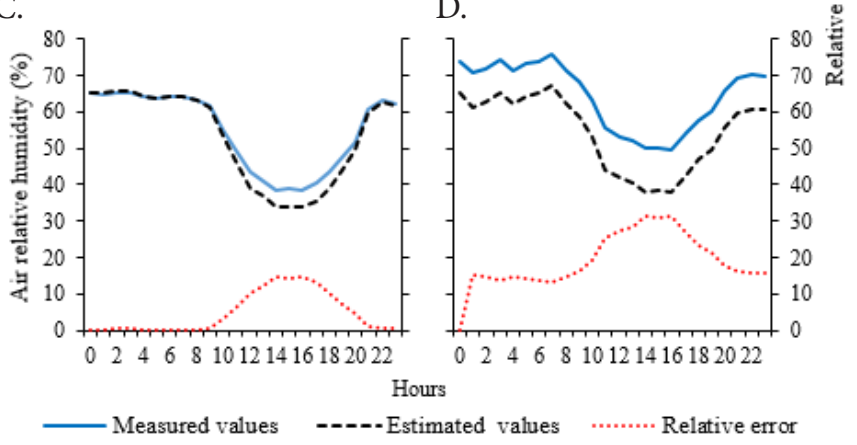

Figure 4. Air temperature and air relative humidity measured and estimated, and relative error: A and C - Experimental Data logger, B and D - Commercial Data logger

the error was 15\% (Figure 4C). The DHT 11 sensor has an accuracy of $\pm 5 \%$ and a lower limit reading of $20 \%$ for air relative humidity measurements. These characteristics may have contributed to the high value of the relative error obtained in the air relative humidity range from 30 to $40 \%$, since these values are close to the lower limit reading of the sensor.

The average relative error of the commercial data logger for the air temperature was $1 \%$. For air temperatures between 20 and $25{ }^{\circ} \mathrm{C}$, the relative error was around $1 \%$ and, at air temperatures above $25^{\circ} \mathrm{C}$, less than $1 \%$ (Figure $4 \mathrm{~B}$ ). The mean relative error calculated for the air relative humidity was $20 \%$. For the air relative humidity in between 60 to $70 \%$ the relative error ranged from 13 to $15 \%$ and for air relative humidity from 30 to $40 \%$ the error was from 16 to $31 \%$ (Figure $4 \mathrm{D}$ ). The air relative humidity values of 30 and $40 \%$ were observed when the environmental temperature was around $30^{\circ} \mathrm{C}$, air temperature and air relative humidity are physically dependent variables which may have contributed to the increase of the relative error. Additionally, sensors for air relative humidity measurements of the commercial data loggers are more sensitive to the variation of air relative humidity according to the manufacturer's specifications.

Djajadi \& Wijanarko (2016) developed a device to monitor air quality based on the Arduino and DHT11 sensor. For the air temperature variable, the developed device presented a reading difference less than $1{ }^{\circ} \mathrm{C}$ and for air relative humidity, a difference of around $10 \%$, compared to the standard device used in the study.

Krishnamurthi et al. (2015) used the Arduino and DHT11 sensor for the development of a climate monitoring device and found satisfactory results regarding reading, acquisition, storage and access to the monitoring database. Similar results were found by Faris \& Mahmood (2014) and Vyas et al. (2016), using these electronic components in a device developed for climate monitoring in greenhouses, and by Handigolkar et al. (2016) and Mahale \& Sonavane (2016) in aviary of broiler. 
In all of the aforementioned studies, there were no results regarding the performance of the devices developed with others already existing commercially, in relation to measured air temperature and air relative humidity data.

\section{Conclusions}

1. The experimental data logger exhibited accuracy and reliability for the thermal conditions found in the aviary once it was calibrated against reference instruments.

2. The calibration equations demonstrated an adequate performance since the standard error of the estimate was smaller than the accuracy provided by the manufacturer and the Nash-Sutcliffe index (NSE) was close to unity.

3. The calibrated experimental data logger presented low relative error in relation to the monitoring of air temperature and especially air relative humidity, when compared with the commercial data logger.

4. The experimental data logger, therefore, is an efficient and reliable device for the characterization of the thermal conditions of aviaries, being able to be used in diverse animal facilities.

\section{ACKnowledgements}

The authors thank the Conselho Nacional de Desenvolvimento Científico e Tecnológico ( $\mathrm{CNPq}$ ), the Coordenação de Aperfeiçoamento de Pessoal de Nível Superior (CAPES), the Fundação de Amparo à Pesquisa do Estado de Minas Gerais (FAPEMIG), the Departamento de Engenharia Agrícola da Universidade Federal de Viçosa (DEA-UFV) and Centro de Pesquisa em Meio Ambiente e Engenharia de Sistemas Agroindustriais (AMBIAGRO) for the grant of a scholarship and financial aid, and also, the farm where the experiment was carried out, for the partnership and assistance in carrying out the study.

\section{Literature Cited}

Ahmad, M. M.; Ghumman, A. R.; Ahmad, S.; Hashmi, H. N. Estimation of a unique pair of Nash model parameters: An optimization approach. Water Resources Management, v.24, p.2971-2989, 2010. https://doi.org/10.1007/s11269-010-9590-3

Chao, K.; Gates, R. S.; Sigrimis, N. Fuzzy logic controller design for staged heating and ventilating systems. Transactions of the American Society of Agricultural Engineers, v.43, p.1885-1894, 2000. https://doi.org/10.13031/2013.3093

Deo, R. C.; Wen, X.; Qi, F. A wavelet-coupled support vector machine model for forecasting global incident solar radiation using limited meteorological dataset. Applied Energy, v.168, p.568-593, 2016. https://doi.org/10.1016/j.apenergy.2016.01.130

Djajadi, A.; Wijanarko, M. Ambient environmental quality monitoring using IoT sensor network. Internetworking Indonesia Journal, v.8, p.41-47, 2016.

D-Robotics. DHT11 humidity \& temperature sensor. Available on: <http://www.micro4you.com/files/sensor/DHT11.pdf>. Accessed on: Mar. 2018.
Faris, D. M.; Mahmood, M. B. Data acquisition of greenhouse using arduino. Journal of Babylon University, v.22, p.1908-1916, 2014.

Gates, R. S.; Chao, K.; Sigrimis, N. Identifying design parameters for fuzzy control of staged ventilation control systems. Computers and Electronics in Agriculture, v.31, p.61-74, 2001. https://doi. org/10.1016/S0168-1699(00)00174-5

Gupta, H. V.; Sorooshian, S.; Yapo, P. O. Status of automatic calibration for hydrologic models: Comparison with multilevel expert calibration. Journal of Hydrologic Engineering, v.4, p.135-143, 1999. https://doi.org/10.1061/(ASCE)1084-0699(1999)4:2(135)

Handigolkar, L. S.; Kavya, M. L.; Veena, P. D. Iot based smart poultry farming using commodity hardware and software. Bonfring International Journal of Software Engineering and Soft Computing, v.6, p.171-175, 2016. https://doi.org/10.9756/ BIJSESC. 8269

Hongqian, C.; Xin, H.; Guanghui, T.; Chaoying, M.; Xiaodong, D.; Taotao, M.; Cheng, W. Cloud-based data management system for automatic real-time data acquisition from large-scale layinghen farms. International Journal of Agricultural and Biological Engineering, v.9, p.106-115, 2016.

Husain, A. M.; Rini, T. H.; Haque, M. I.; Alam, M. R. Air quality monitoring: The use of arduino and android. Journal of Modern Science and Technology, v.4, p.86-96, 2016.

Ji, B.; Zheng, W.; Gates, R. S.; Green, A. R. Design and performance evaluation of the upgraded portable monitoring unit for air quality in animal housing. Computers and Electronics in Agriculture, v.124, p.132-140, 2016. https://doi.org/10.1016/j. compag.2016.03.030

Krishnamurthi, K.; Thapa, S.; Kothari, L.; Prakash, A. Arduino based weather monitoring system. International Journal of Engineering Research and General Science, v.3, p.452-458, 2015.

Li, H.; Wang, H.; Yin, W.; Li, Y.; Qian, Y.; Hu, F. Development of a remote monitoring system for henhouse environment based on IoT technology. Future Internet, v.7, p.329-341, 2015. https:// doi.org/10.3390/fi7030329

Liew, M. W. van; Arnold, J.; Garbrecht, J. D. Hydrologic simulation on agricultural watersheds: Choosing between two models. Transactions of the American Society of Agricultural Engineers, v.46, p.1539-1551, 2003. https://doi.org/10.13031/2013.15643

Ma, L.; Yan, J.; Yan, S.; Wang, B.; Liao, K.; Wang, J. A study of agricultural meteorological monitoring system based on wireless sensor networks. International Journal of Multimedia and Ubiquitous Engineering, v.9, p.15-26, 2014. https://doi. org/10.14257/ijmue.2014.9.7.02

Mahale, R. B.; Sonavane, S. S. Smart poultry farm monitoring using IOT and wireless sensor networks. International Journal of Advanced Research in Computer Science, v.7, p.187-190, 2016.

Miranda, A. C. R.; Pruski, F. F.; Martinez, M. A.; Cecon, P. R. Métodos de separação dos escoamentos superficial direto e subterrâneo: Estudo de caso para a bacia do Rio das Velhas. Revista Brasileira de Recursos Hídricos, v.19, p.169-181, 2014. https://doi.org/10.21168/rbrh.v19n2.p169-181

Moriasi, D. N.; Arnold, J. G.; Liew, M. W. van; Bingner, R. L.; Harmel, R. D.; Veith, T. L. Model evaluation guidelines for systematic quantification of accuracy in watershed simulations. Transactions of the American Society of Agricultural and Biological Engineers, v.50, p.885-900, 2007. https://doi. org/10.13031/2013.23153 
Nash, J. E.; Sutcliffe, J. V. River flow forecasting through conceptual models: Part I - A discussion of principles. Journal of Hydrology, v.10, p.282-290, 1970. https://doi.org/10.1016/0022-1694(70)90255-6

Onset Computer Corporation. $\mathrm{HOBO}^{\circ} \mathrm{U} 14$ loggers: Display, record, and get notified of temperature and humidity conditions. Available on: <http://www.onsetcomp.com/files/datasheet/Onset $\% 20$ HOBO\%20U14\%20Data\%20Loggers.pdf >. Accessed on: Jan. 2018.

Pereira, D. dos R.; Uliana, E. M.; Martinez, M. A.; Silva, D. D. da. Desempenho de um modelo hidrológico concentrado e de um semidistribuído na predição de vazões diárias. Irriga, v.21, p.409424, 2016. https://doi.org/10.15809/irriga.2016v21n2p409-424

Ribas, G. G.; Streck, N. A.; Lago, I.; Zanon, A. J.; Waldow, D. A. G.; Duarte Junior, A. J.; Nascimento, M. de F. do; Fontana, V. Acúmulo de matéria seca e produtividade em híbridos de arroz irrigado simulados com o modelo SimulArroz. Pesquisa Agropecuaria Brasileira, v.51, p.1907-1917, 2016. https://doi. org/10.1590/s0100-204x2016001200001

Roldán, J. J.; Joossen, G.; Sanz, D.; Cerro, J. del; Barrientos, A. Mini-UAV Based sensory system for measuring environmental variables in greenhouses. Sensors, v.15, p.3334-3350, 2015. https://doi.org/10.3390/s150203334
Santhi, C.; Arnold, J. G.; Williams, J. R.; Dugas, W. A.; Srinivasan, R.; Hauck, L. M. Validation of the SWAT Model on a large river basin with point and nonpoint sources. Journal of the American Water Resources Association, v.37, p.1169-1188, 2001. https:// doi.org/10.1111/j.1752-1688.2001.tb03630.x

Torres, J. D.; Monteiro, I. O.; Santos, J. R.; Ortiz, M. S. Weather data acquisition with the Arduino platform: Low cost building and data analysis. Scientia Plena, v.11, p.1-13, 2015.

Ünsal, E.; Milli, M.; Çebi, Y. Low cost wireless sensor networks for environment monitoring. The Online Journal of Science and Technology, v.6, p.61-67, 2016.

Vaisala. User's guide: Vaisala humidity and temperature probes HMP60 and HMP110 series. Available on: <https://www. vaisala.com/sites/default/files/documents/HMP60\%20and\%20 HMP110\%20Series\%20User's\%20Guide\%20in\%20English.pdf>. Accessed on: Mar. 2018.

Vyas, D.; Borole, A.; Singh, S. Smart agriculture monitoring and data acqusition system. International Research Journal of Engineering and Technology, v.3, p.1823-1826, 2016. 